\title{
Hemolysis in Specimen
}

National Cancer Institute

\section{Source}

National Cancer Institute. Hemolysis in Specimen. NCI Thesaurus. Code C70720.

A specimen that has undergone the destruction of red blood cells followed by the release

of the hemoglobin. 